\title{
The Role of Supporting for Learning of Subject in School by Jigsaw Method and Utilizing School Library -Collaboration of School Library and School Music Education (music appreciation) -
}

\author{
Makiko Asano \\ Graduate School Library, Information and Media Studies University of Tsukuba \\ 6-11, Sakura-machi, Kanazawa, Ishikawa, 920-0923 \\ Japan, \\ asanom@slis.tsukuba.ac.jp
}

\section{The Role of Supporting of Learning of Subject in School by Jigsaw Method and Utilizing School Library}

In this study, a music class at a junior high school introduces coordinated activity by the collaboration between a teacher and school library (the Jigsaw Method) in music appreciation. The research investigates what kind of changes the students show through such a type of lesson that they experience for the first time. From the point of teacher's view, the study reveals the evaluation of this lesson support, and what sort of issues it contains. As a result, the lesson support of the school librarian that introduces the book materials and the Jigsaw Method, the teachers obtain a sense of accomplishment more than they expected in the area of learning attitudes and learning contents of the students. Therefore, this research concludes that it is obvious that they have effectiveness in the learning support program which introduces the active learning into the learning support by school library.

Keywords: collaboration, knowledge-constructive jigsaw method, school library, active learning 


\section{References}

Miyake, Naomi, CoREF (University of Tokyo), Kawaijuku. (2016). 協調学習とは一対話を通し て理解を深めるアクティブラーニング- [Collaborative learning - learn more through dialogue active learning type classes -]. Kitaoji Shobo.

Masukawa, Hiroyuki. (2015). 学習科学からの視点一新たな学びと評価への挑戦 [The Viewpoint from Learning Science], Studies of Broadcasting and Media, 12, 189-211.

Griffin, P., McGaw, B. and Care, E., (2014). Assessment and Teaching of 21st Century Skills, Springer. [三宅なほみ監訳, 益川弘如・望月俊男編訳, 21 世紀型スキル一新たな 学びと評価のかたち, 北大路書房]

\section{Biographical note}

Makiko Asano has also worked as a school librarian at two public school libraries in Kanazawa City since April, 2015. As she has Master of cognitive science, she reflects on collaboration in a school education. Her main research is inquiry based-learning on school library and she considers it necessary to adopt an active learning with a school library. 